\title{
Variability evaluation method of socio-geographic and educational parameters
}

\author{
Metoda ocjene varijabilnosti za sociogeografske \\ i obrazovne parametre
}

This paper introduces a method for variability evaluation of a given region (or group of regions) over a given time period, based on the application of a vector of coefficients of variation for socio-geographic and educational parameters. This method introduces a variability measure that implies differences in the quantitative behaviour of these parameters. Classes of similar regions were obtained using $\mathrm{k}$-means cluster analysis. This $\mathrm{pa}^{-}$ per introduces a new general means of educating students about the similarities and differences among regions over a given time period using observed parameters. We applied this method for the Federation of Bosnia and Herzegovina, which is divided in ten cantons and 79 municipalities, using data from the Institute for Statistics of the Federation of Bosnia and Herzegovina. Using this method, major differences in variability were detected in the socio-geographic and educational parameters considered in the paper. Positive socio-geographic and educational parameters were established for 15 municipalities and markedly negative ones for 12 municipalities. With the introduction of the k-means grouping method, it was possible to form five classes of municipalities in which variational measures were different for each class. There were obvious differences between the municipalities of Sarajevo Canton and urban municipalities such as the City of Zenica, the City of Tuzla, and the City of Siroki Brijeg, evident in relation to the number of spatially smaller municipalities and border municipalities.

Key words: k-means clustering, coefficient of variation, the Federation of Bosnia and Herzegovina, sociogeographic processes
Ovaj rad uvodi metodu za ocjenu varijabilnosti pojedinih područja za određeno razdoblje. Zasnovana je na primjeni vektora koeficijenata varijacije sociogeografskih i obrazovnih parametara. Uvodi se mjera varijabilnosti koja podrazumijeva razlike u kvantitativnom ponašanju tih parametara. U upotrebi je i analiza $k$-means-grupiranja za dobivanje razreda sličnih regija. U radu se predstavlja novi opći način edukacije studenata o sličnostima i razlikama među regijama u određenom razdoblju za promatrane parametre. Metoda je primijenjena na Federaciju Bosne i Hercegovine koja je podijeljena na deset kantona i 79 općina. Rad se služi podatcima Federalnoga zavoda za statistiku. Ovom metodom otkrivene su goleme razlike u varijabilnosti sociogeografskih i obrazovnih parametara definiranih u ovom radu. Ustanovljeni su pozitivni sociogeografski i obrazovni parametri za 15 općina i izrazito negativni za 12 općina Federacije Bosne i Hercegovine. Uvođenjem metode $k$-means-grupiranja bilo je moguće formirati 5 klasa općina u kojima su varijacijske mjere različite za svaku klasu. Evidentne su razlike između općina Sarajevske županije i urbanih općina poput Grada Zenice, Grada Tuzle i Grada Širokoga Brijega u odnosu na veći broj prostorno manjih općina i graničnih općina.

Ključne riječi: $k$-means grupiranje, koeficijent varijacije, Federacija Bosne i Hercegovine, sociogeografski procesi 
HRVATSKI

GEOGRAFSKI

GLASNIK

81/2, 89-106 (2019.)

\section{Introduction}

In line with the General Framework Agreement for Peace in Bosnia and Herzegovina (Dayton Peace Agreement, 1995), Bosnia and Herzegovina (B\&H) consists of two entities: Republika Srpska (RS) and the Federation of Bosnia and Herzegovina (the Federation), the latter being divided into ten cantons, mostly ethnically-defined. A further transformation of B\&H's political-territorial organization happened when the arbitration decision regarding the establishment of the Brčko District of $\mathrm{B} \& \mathrm{H}$ (in accordance with paragraph 9 of the Final Arbitration Decision for Brčko, 1999), made by the United Nations High Representative for $\mathrm{B} \& \mathrm{H}$, entered into force. With this decision, the primary division territorial-political organisation of the territory of $\mathrm{B} \& \mathrm{H}$ was expanded. The Brčko District is under direct jurisdiction of the federal entities and state institutions of $\mathrm{B} \& \mathrm{H}$, according to its constitution (Mirić, 2011). This segregated political structure is replicated in the education sector, meaning that there are two autonomous but asymmetrical education systems: one for each constituent entity of $\mathrm{B} \& \mathrm{H}$. This asymmetry is the result of the different educational privileges granted to the two entities.

The Federation's education system is decentralised, with each canton responsible for making its own education policy, including decisions concerning the regulation and provision of education. Since most cantons are ethnically-defined, this decentralisation has ultimately resulted in de facto separate Croat and Bosniak education systems. In contrast, RS has highly-centralised education (Bozic, 2006). The exception is the Žepče Municipality in the Zenica-Doboj Canton where, for the first time, a case was reported of jurisdiction over elementary and secondary education transferring to one local community in the Federation, and the Supreme Court of the Federation ${ }^{1}$.

The main characteristics and challenges of the present-day educational system in $\mathrm{B} \& \mathrm{H}$ are: the highly politicised nature of education; large number of laws regulating education; lack of sufficient support for science and research in education; lack of a legal framework regulating these important parts of the educational process; lack of federal educational standards;

\footnotetext{
1 https://zepce.ba/index.php/zepce/item/1162-osnovno-i-srednjeobrazovanje-preneseno-u-nadleznostopcine-zepce
}

\section{Uvod}

U skladu s Općim okvirnim sporazumom za mir u Bosni i Hercegovini (Dejtonski mirovni sporazum) potpisanim 1995. godine Bosna i Hercegovina sastoji se od dvaju entiteta, Republike Srpske (RS) i Federacije Bosne i Hercegovine ( $\mathrm{FBiH}$, Federacija), posljednja je podijeljena u deset županija, uglavnom etnički definiranih. U daljnjoj transformaciji političko-teritorijalne organizacije $\mathrm{BiH}$ arbitražnom odlukom visokoga predstavnika Ujedinjenih naroda za $\mathrm{BiH}$ (u skladu sa stavkom 9. Konačne arbitražne odluke za Brčko od 5. ožujka 1999.) stupila je na snagu odredba o osnivanju Distrikta Brčko BiH. Ovom odlukom proširena je teritorijalno-politička organizacija teritorija $\mathrm{BiH}$ u primarnoj podjeli jer je Distrikt Brčko prema ustavu u neposrednoj nadležnosti institucija entiteta i državnih institucija BiH (Mirić, 2011). Ova politička struktura ima svoju replikaciju u sektoru obrazovanja, dijeleći je u dva autonomna ali asimetrična obrazovna sustava na razini entiteta. Ta se asimetrija može pripisati različitim obrazovnim obvezama koje su dodijeljene entitetima.

Obrazovni sustav Federacije je decentraliziran, a svaka županija odgovorna je za izradu svoje obrazovne politike, uključujući i odluke koje se odnose na propise i usluge obrazovanja. Budući da je većina županija etnički definirana, ta je decentralizacija naposljetku rezultirala de facto hrvatskim i bošnjačkim obrazovnim sustavima. Nasuprot tomu, RS ima visoko centralizirano obrazovanje (Bozic, 2006). Izuzetak je općina Žepče u Zeničko-dobojskoj županiji, gdje je po prvi put zabilježen slučaj prenošenja nadležnosti osnovnoga i srednjega obrazovanja na jednu lokalnu zajednicu u FBiH, shodno Vrhovnom sudu FBiH. ${ }^{1}$

Glavna obilježja i izazovi današnjega obrazovnog sustava u $\mathrm{BiH}$ su: visoko politizirana priroda obrazovanja, velik broj zakona kojima se regulira obrazovanje, neuspjeh u podržavanju znanosti i istraživanja u obrazovanju, nedostatak zakonskoga okvira koji regulira ovaj važan dio obrazovnoga procesa, nedostatak obrazovnih standarda, kuri-

\footnotetext{
1 https://zepce.ba/index.php/zepce/item/1162-osnovno-i-srednjeobrazovanje-preneseno-u-nadleznostopcine-zepce
} 
lack of curricula corresponding to EU requirements in terms of goals and educational outcomes; and a shortage of teachers with educational backgrounds appropriate for responding quickly and efficiently to the needs of the labour market (Pasalić-Kreso, 2008).

Pursuant to the Law on Ministries and Other Bodies of the B\&H Administration, the Ministry of Civil Affairs of $\mathrm{B} \& \mathrm{H}$ is in charge of performing tasks in the jurisdiction of $\mathrm{B} \& \mathrm{H}$ that are related to the establishment of basic principles of coordination of activities, harmonisation of the plans of the entity authorities, and defining the strategy on the international level, among others, for the field of education so bodies have formed for the coordination of the education sector: the Conference of Ministers of Education in B\&H and the Council for General Education in B\&H. ${ }^{2}$

\section{Previous research}

The decentralisation of power in Bosnia and Herzegovina and the transfer of educational and pedagogical issues to lower-level entities (cantons, municipalities, and districts), has led to a situation where certain state bodies that should be involved in the education management process are not. In this way, with the exception of the Institute for Statistics of the Federation of Bosnia Herzegovina, it is difficult to keep track of educational data and other socio-geographic parameters. Moreover, there is often a lack of a single database to store common data. Cantons make their strategies, bring key strategic goals, revise curricula, and make projections in the field of education and socio-geographic trends independently of one another. The separation between ethnicities extends deeply into the education system. Schooling is characterised by mono-ethnic classrooms, segregated schools, opposed pedagogies, and a total absence of a common curriculum (Stabback, 2007).

International non-governmental organisations (NGOs) and community-based organisations have further maintained policy fragmentation, due to their lack of unity and the absence of common goals regarding their activities (Stabback, 2007; Jancic, 2008). Fragmentation, segregation, and politicisa-

2 http://www.mcp.gov.ba/org_jedinice/sektor_obrazovanje/Osnovne_ informacije/default.aspx?id=8580\&lang $\mathrm{T}$ ag=bs-BA kuli koji ne odgovaraju zahtjevima EU-a shodno ciljevima i odgojno-obrazovnim ishodima, manjak nastavnika s odgovarajućim obrazovanjem za brzo i učinkovito reagiranje na potrebe tržišta rada (Pasalić-Kreso, 2008).

Sukladno Zakonu o ministarstvima i drugim tijelima Uprave $\mathrm{BiH}$ Ministarstvo civilnih poslova $\mathrm{BiH}$ zaduženo je za izvršavanje zadataka i obavljanje poslova iz nadležnosti $\mathrm{BiH}$, a vezano je za uspostavljanje osnovnih principa koordinacije aktivnosti, harmonizacije planova entitetskih vlasti i definiranja strategije na međunarodnoj razini, između ostaloga, za područje obrazovanja te su formirana tijela za koordinaciju sektora obrazovanja: Konferencija ministara obrazovanja u $\mathrm{BiH}$ i Vijeće za opće obrazovanje u $\mathrm{BiH}{ }^{2}$

\section{Dosadašnja istraživanja}

Decentralizacija vlasti u Bosni i Hercegovini i prijenos obrazovnih i pedagoških pitanja na entitete niže razine (županije, općine i distrikt) dovode do činjenice da nekoliko državnih tijela nije koordinirano u procesu upravljanja obrazovanjem. $\mathrm{Na}$ taj način, s izuzetkom Federalnoga zavoda za statistiku, teško je pratiti obrazovne podatke i druge sociogeografske parametre, pa često nedostaje jedinstvena baza podataka za pohranu zajedničkih podataka. Županije donose svoje strategije, donose ključne strateške ciljeve i revidiraju kurikul i napredne projekcije u području obrazovanja i sociogeografskih trendova. Razdvajanje etničkih skupina proširilo se i na obrazovni sustav. Školstvo karakteriziraju monoetničke učionice, segregirane škole, suprotstavljene pedagogije i nepostojanje zajedničkoga nastavnog plana i programa (Stabback, 2007).

Međunarodne nevladine organizacije (NVO) i organizacije utemeljene u zajednicama dodatno su održavale fragmentiranu politiku zbog nedostatka jedinstva i nepostojanja zajedničkoga cilja u svojim aktivnostima za obrazovni sustav (Stabback, 2007; Jancic 2008). Fragmentacija, segregacija i politizacija traumatiziranoga i slomljenoga poslijeratnog

\footnotetext{
2 http://www.mcp.gov.ba/org_jedinice/sektor_obrazovanje/Osnovne_ informacije/default.aspx?id=8580\&langT ag=bs-BA 
HRVATSKI

GEOGRAFSKI

GLASNIK

81/2, 89-106 (2019.) tion of a traumatised and broken post-war society have permeated into all aspects of the education system, transforming the dialogue of understanding and social cohesion into one of opposing ideologies, hatred, and mistrust (Jancic, 2008).

Primary education in the Federation is mandatory and lasts for nine years. The latest reforms in the field of education changed the duration of primary education from eight to nine years. The eight-year primary school duration has been extended for one school year, meaning that students begin their primary school education at age six (Jahić, 2015).

The cantonal ministries of education (many of which are also responsible for education, science, culture, and sports) have authority over education. Their size and capacity to perform functions differ from canton to canton. Municipalities with defined regulations in education are able to determine local-level competencies in the education sector independently.

According to the data from the Institute for Statistics of the Federation of Bosnia and Herzegovina $(2008 ; 2012 ; 2015 ; 2017)$, the number of primary schools in the Federation has decreased by $2.2 \%$ in the last ten years (2008-2017). In other words, in the same period, 24 primary schools were closed, most in Tuzla Canton, Una-Sana Canton, and West-Herzegovina Canton.

According to the data from the Institute for Statistics of the Federation of Bosnia and Herzegovina (1997; 2002; 2007; 2017), the general assessment is that all cantons in the Federation recorded a decrease in birth rate in the period of 1996-2017; whereby only Sarajevo Canton stands out, with a relative decrease in the total birth rate $(9.5 \%)$ that is much lower than in all other cantons. There is no doubt that the reduced birth rate and associated fertility rate are among the key reasons for the decreasing total number of primary school pupils in all cantons in the Federation. The only exception is Sarajevo, where a decrease in the total birth rate has been recorded; however, due to immigration, this is the only canton in which the number of primary school pupils increased over the observed period. društva prodrli su u sve aspekte obrazovnoga sustava, pretvarajući nekadašnji način dijaloga, veće razumijevanje i socijalnu koheziju u jednu od suprotstavljenih ideologija, mržnju i nepovjerenje (Jancic 2008).

Osnovno je obrazovanje u Federaciji Bosne i Hercegovine obvezno i traje devet godina. Najnovije reforme u području obrazovanja promijenile su trajanje osnovnoga obrazovanja s osam na devet godina. Trajanje osmogodišnje osnovne škole produženo je za jednu školsku godinu, što znači da su učenici pohađali školovanje od šeste godine života (Jahić, 2015).

Županijska ministarstva obrazovanja (od kojih su mnoga odgovorna za obrazovanje, znanost, kulturu i sport) imaju zapravo vlast nad obrazovanjem. Njihova veličina i sposobnost za obavljanje funkcija razlikuju se od županije do županije. Općine s definiranim propisima u obrazovanju različito određuju nadležnosti na lokalnoj razini u sektoru obrazovanja.

Prema podatcima Federalnoga zavoda za statistiku $(2008 ; 2012 ; 2015 ; 2017$.) broj osnovnih škola u Federaciji Bosne i Hercegovine u posljednjih deset godina $(2008$ - 2017) smanjen je za 2,2 \%. Drugim riječima, u istom razdoblju zatvorene su 24 osnovne škole, pri čemu je većina zatvorenih škola u Tuzlanskoj županiji, Unsko-sanskoj županiji i Zapadnohercegovačkoj županiji.

Prema podatcima Federalnoga zavoda za statistiku $(1997 ; 2002 ; 2007 ; 2017)$ opća je ocjena da su sve županije u Federaciji Bosne i Hercegovine zabilježile pad nataliteta u razdoblju od 1996. do 2017., pri čemu se razlikuje samo $\check{Z} u-$ panija Sarajevo, čiji je relativni pad ukupne stope nataliteta $9,5 \%$ i još uvijek je mnogo manji nego u svim drugim županijama. Nema sumnje da su smanjenje nataliteta i pripadajuća stopa fertiliteta među ključnim razlozima za smanjenje ukupnoga broja učenika osnovnih škola u svim županijama u Federaciji Bosne i Hercegovine. Iznimka je Sarajevo gdje se bilježi smanjenje ukupne stope nataliteta, ali je i dalje jedina županija u kojoj je očigledno povećanje broja učenika osnovnih škola za promatrano razdoblje od deset godina. 
The situation regarding change in the number of pupils in secondary schools in municipalities and cantons is similar because, except for Sarajevo Canton, all cantons have recorded a decrease in the number of pupils. There are also negative trends in the number of higher-education students, and even state universities have observed decreased enrolment in comparison to private or foreign universities. The analysis of other socio-geographic parameters (birth and death rates, migration rate, number of employees, and the average net salary) reveal very uneven and mostly negative trends for most cantons in the Federation. This is particularly expressed for more than two-thirds of its municipalities.

\section{Methods}

What the actual trends are and whether there has been significant change in the last ten-year period can be detected by researching the variability of the mentioned parameters. This opens the possibility of using the coefficient of variation, the measure of variability for all municipalities, and also the very reliable methods of $\mathrm{k}$-means clustering that will serve to classify 79 municipalities in the Federation into groups of municipalities or so-called classes, where all elements of one class or all municipalities of one class have similar characteristics. This will, in fact, make the categorisation of municipalities possible, thus determining the degree of socio-geographical inequality in the Federation, and also creating a clearer picture of the situation in the trends of primary education for the same area.

\section{Vector of coefficients of variation}

Let $\chi_{1}, \ldots, \chi_{1}$ be real numbers that represent some measured parameter for 1 years. The coefficient of variation for these numbers is defined by

$$
c_{v}=\frac{\sigma}{\mu}
$$

where

$$
\mu=\frac{1}{l} \sum_{i=1}^{l} x_{i}
$$

Slična je situacija i s kretanjem broja učenika u srednjim školama u općinama i županijama jer sve županije, osim Županije Sarajevo, bilježe smanjenje broja učenika. Postoje i negativni trendovi u kretanju broja studenata, gdje čak i najpoznatija državna sveučilišta gube studente koji dominantno prelaze na privatna sveučilišta ili zbog iseljavanja studiraju u zapadnoeuropskim i drugim zemljama. Analiza ostalih sociogeografskih parametara, kao što su stopa rođenja i smrtnosti, stopa migracije, broj zaposlenih i prosječna neto plaća otkrivaju vrlo neujednačene i uglavnom negativne trendove za većinu županija u Federaciji Bosne i Hercegovine, a posebno za više od $2 / 3$ općina.

\section{Metode}

Koji je stvarni trend i je li došlo do bitnije promjene u posljednjem desetogodišnjem razdoblju može se otkriti istraživanjem varijabilnosti navedenih parametara, što otvara mogućnost korištenja koeficijenta varijacije, mjere varijabilnosti za sve općine, ali i vrlo pouzdane metode $k$-means grupiranja koje će poslužiti za klasificiranje 79 općina u entitetu Federacije Bosne i Hercegovine u skupine općina ili tzv. klase gdje svi elementi jedne klase ili svih općina jedne klase imaju slična obilježja. To će u biti omogućiti kategorizaciju općina te na taj način odrediti stupanj sociogeografske nejednakosti u entitetu Federacije Bosne i Hercegovine, ali i stvoriti jasniju sliku stanja u trendovima primarnoga obrazovanja za isto područje.

\section{Vektor koeficijenata varijacije}

Neka su $\chi_{1}, \ldots, \chi_{1}$ realni brojevi koji predstavljaju mjerene veličine za 1 godina. Koeficijent varijacije za ove brojeve definiran je s

$$
\begin{aligned}
& \qquad c_{v}=\frac{\sigma}{\mu} \\
& \text { gdje je } \\
& \mu=\frac{1}{l} \sum_{i=1}^{l} x_{i}
\end{aligned}
$$

Variability

evaluation method of socio-geographic and educational parameters

Metoda ocjene varijabilnosti sociogeografskih i obrazovnih parametara 
as a mean value and $\sigma$ is the standard deviation defined by

$$
\sigma=\sqrt{\frac{\sum_{i=1}^{l}\left(x_{i}-\mu\right)^{2}}{l-1}}
$$

If we have $n$ parameters, then we obtain a vector of $n$ coefficients of variation

$$
\left(c_{v 1}, \ldots, c_{v n}\right) \text {. }
$$

Every municipality ${ }^{3}$ is represented in this way, where coefficients of variation were obtained from data obtained from the Institute for Statistics of the Federation of Bosnia and Herzegovina. The reason we used this approach is interconnectedness of parameters.

The coefficient of variation is a widely-used as a tool in various areas of science (Reed et al., 2002; Kozak et al., 2013). In this paper it represents changes in socio-geographic processes for a given time period. Eight parameters related to each municipality were considered: birth rate; mortality rate; number of immigrants; number of emigrants; number of pupils in primary schools; average salary; unemployment rate; and employment rate. Among the key reasons for choosing these parameters was that they gave an excellent picture of contemporary socio-geographical processes. The vector of coefficient of variations were obtained in the listed order. All these parameters were used inside the vector because they were interconnected.

These parameters were calculated from data obtained from Institute for Statistics of the Federation of Bosnia and Herzegovina during the period of 2008-2017.

The value of variability measure of municipality is defined using $\chi=\left(c_{v 1}, \ldots, c_{v n}\right)$ by

$$
f(x)=\sum_{i=1}^{n} c_{v_{i}}^{2}
$$

We call this function the "municipality measure of variability". It also defines the variability measure

3 The lowest administrative-territorial units within the Federation of Bosnia and Herzegovina (total of 79) srednja vrijednost i $\sigma$ standardna devijacija definirana s

$$
\sigma=\sqrt{\frac{\sum_{i=1}^{l}\left(x_{i}-\mu\right)^{2}}{l-1}}
$$

Ako postoji n parametara, tada se dobiva vektor od $n$ koeficijenata varijacije

$$
\left(c_{v 1}, \ldots, c_{v n}\right) \text {. }
$$

$\mathrm{Na}$ ovaj način svaka općina ${ }^{3}$ nalazi svoju zastupljenost, gdje su koeficijenti varijacije dobiveni iz podataka dobivenih od Federalnoga zavoda za statistiku. Razlog zbog kojega se koristi ovaj pristup je međusobna povezanost parametara.

Široka je upotreba koeficijenta varijacije kao alata u različitim područjima znanosti (Reed i dr., 2002; Kozak i dr., 2013). U ovom su radu prikazane promjene $\mathrm{u}$ sociogeografskim procesima za određeno razdoblje. Razmatra se osam parametara koji se odnose na svaku općinu: natalitet, mortalitet, broj imigranata, broj emigranata, broj učenika u osnovnoj školi, prosječna plaća, stopa nezaposlenosti, stopa zaposlenosti. Jedan od ključnih razloga za odabir navedenih parametara jest u tome što ti parametri daju odličnu sliku stanja suvremenih sociogeografskih procesa. Vektor koeficijenata varijacije dobiva se u tom redoslijedu. Koriste se svi parametri unutar vektora jer su međusobno povezani.

Ti su parametri izračunati iz podataka dobivenih od Federalnoga zavoda za statistiku u razdoblju od 2008. do 2017.

Definira se mjera varijabilnosti općine

$$
\begin{gathered}
\chi=\left(c_{v 1}, \ldots, c_{v n}\right) s \\
f(x)=\sum_{i=1}^{n} c_{v_{i}}{ }^{2}
\end{gathered}
$$

Ova funkcija nazvana je „mjera varijabilnosti općine". Također, definira se mjera varijabilnosti neke

\footnotetext{
3 Najmanje administrativno-teritorijalne jedinice u Federaciji Bosne i Hercegovine (ukupno 79).
} 
of a given subset to be the mean value of the variability measures of their elements, i.e.

$$
f(S)=\frac{\sum_{x \in S} f(x)}{|S|}
$$

where $\mathscr{D}$ is the set of all municipalities in the Federation, $S \subseteq \mathscr{D}$, and $|S|$ is its number of elements.

For different parameters, a value of measurability of variation higher than 0.2 shows high variability or a high rate of change. From 0.1 to 0.2 it shows median changes and below 0.1 it shows stable and almost unchanging processes. This implies that viewing vectors of coefficients of variation gives us a more accurate picture of variability of a certain process, which can be socio-geographic, educational, economic, etc.

The Federation has ten administrative areas called cantons which represent the second level of administrative territorial division of the Federation of Bosnia and Herzegovina. Every canton contains a certain number of municipalities. In this paper we calculated the measure of variability of each canton. Table 1 presents the obtained results for municipalities, as well as their variability measures and Table 2 shows the appropriate measure of variability by canton. We rounded every value to two decimal places after the decimal point.

There are many reasons for the high values of certain measures of variability for the municipalities. The most important are: negative migration processes; decline in population dynamics; decline in the number of pupils in primary schools; low average salary; and the dominant process of population aging. Conversely, there are municipalities with low values in certain measures of variability, mostly due to positive socio-geographic processes: immigration processes; increasing of numbers of pupils in primary schools; increasing natural and overall population dynamics; and living standard improvements-which are visible through average salary increases and increasing employment rates. This tells us that municipalities and cantons with lower values of measure of variability actually have positive socio-geographic and educational parameters. podskupine kao srednja vrijednost mjera varijabilnosti njihovih elemenata, $t \mathrm{j}$.

$$
f(S)=\frac{\sum_{x \in S} f(x)}{|S|}
$$

gdje je $\mathscr{D}$ skup svih općina u Federaciji Bosne i Hercegovine, $S \subseteq \mathcal{D}$, a $|S|$ je njihov broj elemenata.

$\mathrm{Za}$ različite vrijednosti mjerenje varijacije veće od 0,2 pokazuje visoku varijabilnost odnosno velike promjene. Od 0,1 do 0,2 pokazuje posredne promjene, a ispod 0,1 pokazuje stabilne i gotovo nepromjenjive procese. To znači da promatranje vektora koeficijenata varijacije daje točniju sliku varijabilnosti određenoga procesa, koji može biti sociogeografski, obrazovni, ekonomski, itd.

Kao što je već spomenuto, Federacija Bosne i Hercegovine sastoji se od deset administrativnih područja zvanih županije, a svaka županija od određenoga broja općina. U ovom se radu izračunava mjera varijabilnosti svake županije. Tablica 1 predstavlja dobivene rezultate za općine, kao i njihove mjere varijabilnosti, a Tablica 2 odgovarajuću mjeru varijabilnosti za pripadajuću županiju. Svaka vrijednost zaokružuje se dvama decimalnim mjestima nakon decimalne točke.

Razlozi za visoke vrijednosti pojedinih mjera varijabilnosti općina su višestruki. Najvažniji su: negativni migracijski procesi, pad populacijske dinamike, pad broja učenika u osnovnim školama, niska vrijednost prosječne plaće, dominantan proces starenja stanovništva. S druge strane, postoje općine s niskim mjerama varijabilnosti, uglavnom zbog pozitivnih sociogeografskih procesa: imigracijski proces, povećanje broja učenika u osnovnim školama, povećanje prirodne i ukupne dinamike populacije, poboljšanje životnoga standarda, što je vidljivo u povećanju prosječne plaće i većem broju zaposlenih. To nam govori da općine i županije s nižim vrijednostima mjere varijabilnosti zapravo imaju pozitivne sociogeografske i obrazovne parametre. parameters

Metoda ocjene varijabilnosti sociogeografskih i obrazovnih parametara 
HRVATSKI

GEOGRAFSKI

GLASNIK

81/2, 89-106 (2019.)
Tab. 1 Vector of coefficients of variation and measure of variability for the period 2008-2017.

Tab. 1. Vektor koeficijenata varijacije i mjera varijabilnosti za period 2008-2017.

\begin{tabular}{|c|c|c|c|c|c|c|c|c|c|}
\hline 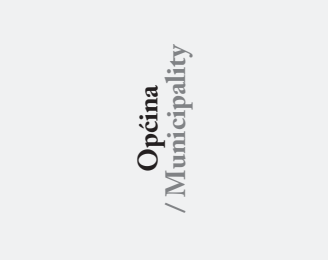 & 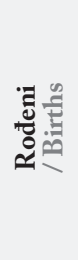 & 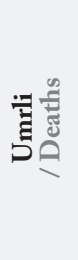 & 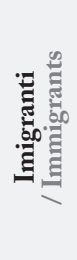 & 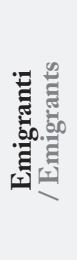 & 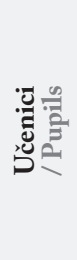 & 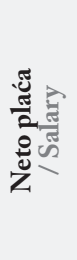 & 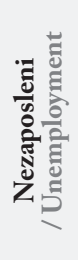 & 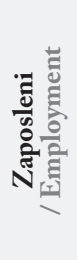 & 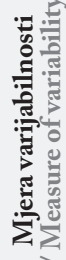 \\
\hline CENTAR & 0.05 & 0.05 & 0.18 & 0.15 & 0.06 & 0.05 & 0.05 & 0.03 & 0.07 \\
\hline HADŽIĆI & 0.06 & 0.09 & 0.17 & 0.37 & 0.05 & 0.05 & 0.04 & 0.07 & 0.19 \\
\hline ILIDŽA & 0.04 & 0.08 & 0.27 & 0.33 & 0.05 & 0.05 & 0.05 & 0.10 & 0.21 \\
\hline ILIJAŠ & 0.05 & 0.10 & 0.24 & 0.30 & 0.03 & 0.04 & 0.04 & 0.27 & 0.24 \\
\hline NOVI GRAD & 0.06 & 0.05 & 0.16 & 0.20 & 0.06 & 0.04 & 0.05 & 0.1 & 0.09 \\
\hline NOVO SARAJEVO & 0.19 & 0.04 & 0.18 & 0.18 & 0.03 & 0.05 & 0.06 & 0.04 & 0.11 \\
\hline STARI GRAD & 0.09 & 0.05 & 0.18 & 0.17 & 0.11 & 0.05 & 0.05 & 0.04 & 0.09 \\
\hline TRNOVO (FBiH) & 0.32 & 0.20 & 1,98 & 1,07 & 0.21 & 0.02 & 0.08 & 0.14 & 5,27 \\
\hline VOGOŠĆA & 0.09 & 0.14 & 0.18 & 0.25 & 0.04 & 0.03 & 0.05 & 0.14 & 0.12 \\
\hline BOSANSKA KRUPA & 0.16 & 0.07 & 0.18 & 0.21 & 0.13 & 0.05 & 0.07 & 0.07 & 0.14 \\
\hline BOSANSKI PETROVAC & 0.19 & 0.08 & 0.12 & 0.15 & 0.15 & 0.09 & 0.06 & 0.10 & 0.12 \\
\hline BUŽIM & 0.12 & 0.09 & 0.17 & 0.20 & 0.11 & 0.05 & 0.22 & 0.10 & 0.16 \\
\hline CAZIN & 0.16 & 0.04 & 0.17 & 0.15 & 0.08 & 0.03 & 0.08 & 0.09 & 0.09 \\
\hline GRAD BIHAĆ & 0.12 & 0.05 & 0.14 & 0.15 & 0.17 & 0.06 & 0.16 & 0.04 & 0.12 \\
\hline KLJUČ & 0.20 & 0.08 & 0.07 & 0.13 & 0.22 & 0.07 & 0.07 & 0.10 & 0.14 \\
\hline SANSKI MOST & 0.14 & 0.08 & 0.16 & 0.13 & 0.20 & 0.07 & 0.05 & 0.07 & 0.12 \\
\hline VELIKA KLADUŠA & 0.16 & 0.05 & 0.13 & 0.16 & 0.05 & 0.05 & 0.10 & 0.08 & 0.09 \\
\hline BANOVIĆI & 0.05 & 0.09 & 0.16 & 0.11 & 0.10 & 0.06 & 0.04 & 0.03 & 0.06 \\
\hline ČELIĆ & 0.14 & 0.10 & 0.15 & 0.10 & 0.12 & 0.03 & 0.04 & 0.10 & 0.09 \\
\hline DOBOJ-ISTOK & 0.13 & 0.20 & 0.19 & 0.10 & 0.06 & 0.03 & 0.08 & 0.16 & 0.14 \\
\hline VAREŠ & 0.28 & 0.10 & 0.13 & 0.19 & 0.18 & 0.07 & 0.24 & 0.08 & 0.24 \\
\hline VISOKO & 0.14 & 0.05 & 0.12 & 0.19 & 0.04 & 0.05 & 0.16 & 0.06 & 0.10 \\
\hline ZAVIDOVIĆI & 0.20 & 0.06 & 0.10 & 0.08 & 0.10 & 0.11 & 0.27 & 0.19 & 0.19 \\
\hline GRAD ZENICA & 0.08 & 0.05 & 0.11 & 0.10 & 0.09 & 0.07 & 0.03 & 0.03 & 0.04 \\
\hline ŽEPČE & 0.11 & 0.06 & 0.13 & 0.13 & 0.12 & 0.04 & 0.23 & 0.17 & 0.15 \\
\hline FOČA-FBIH & 0.19 & 0.21 & 0.46 & 0.25 & 0.19 & 0.10 & 0.28 & 0.09 & 0.48 \\
\hline GORAŽDE & 0.10 & 0.08 & 0.16 & 0.36 & 0.15 & 0.02 & 0.14 & 0.14 & 0.24 \\
\hline PALE-FBIH & 0.40 & 0.41 & 0.43 & 0.30 & 0.19 & 0.04 & 0.26 & 0.08 & 0.72 \\
\hline BUGOJNO & 0.11 & 0.05 & 0.10 & 0.12 & 0.13 & 0.10 & 0.24 & 0.10 & 0.13 \\
\hline BUSOVAČA & 0.12 & 0.06 & 0.12 & 0.17 & 0.11 & 0.08 & 0.28 & 0.11 & 0.17 \\
\hline DONJI VAKUF & 0.14 & 0.08 & 0.13 & 0.1 & 0.14 & 0.09 & 0.29 & 0.20 & 0.20 \\
\hline FOJNICA & 0.13 & 0.08 & 0.11 & 0.13 & 0.15 & 0.08 & 0.20 & 0.05 & 0.12 \\
\hline $\begin{array}{c}\text { GORNJI } \\
\text { VAKUF-USKOPLJE }\end{array}$ & 0.11 & 0.11 & 0.08 & 0.17 & 0.15 & 0.10 & 0.27 & 0.08 & 0.18 \\
\hline JAJCE & 0.14 & 0.18 & 0.12 & 0.15 & 0.12 & 0.11 & 0.27 & 0.08 & 0.20 \\
\hline KISELJAK & 0.15 & 0.06 & 0.18 & 0.18 & 0.10 & 0.06 & 0.19 & 0.10 & 0.15 \\
\hline KREČEVO & 0.17 & 0.14 & 0.14 & 0.21 & 0.17 & 0.14 & 0.17 & 0.07 & 0.19 \\
\hline DOBRETIĆI & 0.43 & 0.46 & 0.55 & 0.35 & 0.43 & 0.14 & 0.17 & 0.13 & 1,08 \\
\hline NOVITRAVNIK & 0.07 & 0.09 & 0.15 & 0.12 & 0.14 & 0.09 & 0.25 & 0.15 & 0.16 \\
\hline TRAVNIK & 0.11 & 0.09 & 0.08 & 0.12 & 0.35 & 0.25 & 0.12 & 0.09 & 0.25 \\
\hline VITEZ & 0.09 & 0.10 & 0.08 & 0.17 & 0.12 & 0.06 & 0.16 & 0.12 & 0.11 \\
\hline
\end{tabular}




\begin{tabular}{|c|c|c|c|c|c|c|c|c|c|}
\hline 总 & 苛 & 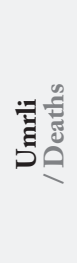 & 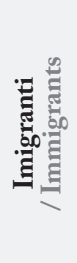 & 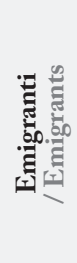 & 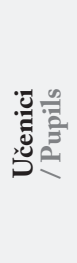 & 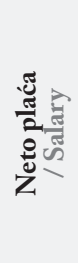 & 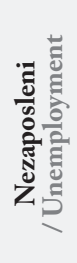 & 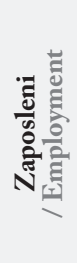 & 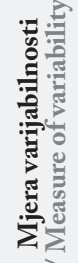 \\
\hline GRAČANICA & 0.13 & 0.08 & 0.07 & 0.25 & 0.09 & 0.04 & 0.06 & 0.08 & 0.11 \\
\hline GRADTUZLA & 0.06 & 0.06 & 0.13 & 0.17 & 0.10 & 0.02 & 0.05 & 0.04 & 0.07 \\
\hline GRADAČAC & 0.08 & 0.05 & 0.15 & 0.25 & 0.12 & 0.02 & 0.04 & 0.11 & 0.12 \\
\hline KALESIJA & 0.13 & 0.08 & 0.19 & 0.14 & 0.13 & 0.02 & 0.06 & 0.13 & 0.12 \\
\hline KLADANJ & 0.15 & 0.07 & 0.14 & 0.07 & 0.17 & 0.02 & 0.04 & 0.07 & 0.09 \\
\hline LUKAVAC & 0.14 & 0.07 & 0.14 & 0.16 & 0.13 & 0.03 & 0.05 & 0.03 & 0.09 \\
\hline SAPNA & 0.21 & 0.17 & 0.27 & 0.16 & 0.23 & 0.08 & 0.06 & 0.12 & 0.24 \\
\hline SREBRENIK & 0.14 & 0.09 & 0.21 & 0.30 & 0.07 & 0.02 & 0.08 & 0.08 & 0.18 \\
\hline TEOČAK & 0.22 & 0.14 & 0.28 & 0.24 & 0.15 & 0.03 & 0.07 & 0.04 & 0.23 \\
\hline ŽIVINICE & 0.12 & 0.09 & 0.09 & 0.13 & 0.09 & 0.05 & 0.06 & 0.06 & 0.06 \\
\hline $\begin{array}{l}\text { DOMALJEVAC } \\
\text {-SAMAC }\end{array}$ & 0.34 & 0.07 & 0.28 & 0.46 & 0.32 & 0.03 & 0.07 & 0.08 & 0.54 \\
\hline ODŽAK & 0.20 & 0.07 & 0.13 & 0.15 & 0.17 & 0.04 & 0.05 & 0.09 & 0.13 \\
\hline ORAŠJE & 0.17 & 0.08 & 0.18 & 0.66 & 0.21 & 0.04 & 0.04 & 0.06 & 0.55 \\
\hline BREZA & 0.13 & 0.06 & 0.14 & 0.23 & 0.14 & 0.10 & 0.22 & 0.02 & 0.18 \\
\hline DOBOJ-JUG & 0.17 & 0.16 & 0.14 & 0.14 & 0.06 & 0.06 & 0.24 & 0.13 & 0.18 \\
\hline KAKANJ & 0.12 & 0.10 & 0.05 & 0.07 & 0.14 & 0.08 & 0.24 & 0.13 & 0.13 \\
\hline MAGLAJ & 0.10 & 0.07 & 0.13 & 0.15 & 0.13 & 0.07 & 0.27 & 0.13 & 0.17 \\
\hline OLOVO & 0.27 & 0.11 & 0.17 & 0.24 & 0.18 & 0.04 & 0.23 & 0.09 & 0.27 \\
\hline TEŠANJ & 0.07 & 0.06 & 0.08 & 0.1 & 0.08 & 0.02 & 0.19 & 0.15 & 0.09 \\
\hline USORA & 0.25 & 0.20 & 0.29 & 0.13 & 0.30 & 0.14 & 0.29 & 0.31 & 0.49 \\
\hline ČAPLJINA & 0.10 & 0.15 & 0.16 & 0.33 & 0.14 & 0.03 & 0.2 & 0.01 & 0.23 \\
\hline ČITLUK & 0.15 & 0.11 & 0.20 & 0.22 & 0.10 & 0.06 & 0.11 & 0.20 & 0.19 \\
\hline JABLANICA & 0.15 & 0.10 & 0.22 & 0.11 & 0.12 & 0.07 & 0.28 & 0.08 & 0.19 \\
\hline KONJIC & 0.15 & 0.08 & 0.14 & 0.25 & 0.13 & 0.07 & 0.22 & 0.10 & 0.19 \\
\hline GRAD MOSTAR & 0.03 & 0.05 & 0.19 & 0.17 & 0.09 & 0.05 & 0.09 & 0.07 & 0.09 \\
\hline NEUM & 0.68 & 0.39 & 0.29 & 0.16 & 0.14 & 0.08 & 0.10 & 0.05 & 0.76 \\
\hline PROZOR & 0.18 & 0.23 & 0.20 & 0.25 & 0.17 & 0.06 & 0.26 & 0.10 & 0.3 \\
\hline STOLAC & 0.15 & 0.08 & 0.77 & 0.24 & 0.18 & 0.27 & 0.28 & 0.11 & 0.88 \\
\hline RAVNO & 0.85 & 0.82 & 0.62 & 0.3 & 0.22 & 0.14 & 0.15 & 0.24 & 2,02 \\
\hline GRUDE & 0.09 & 0.16 & 0.18 & 0.19 & 0.10 & 0.10 & 0.15 & 0.13 & 0.17 \\
\hline LJUBUŠKI & 0.05 & 0.11 & 0.32 & 0.25 & 0.10 & 0.08 & 0.17 & 0.04 & 0.23 \\
\hline POSUŠJE & 0.11 & 0.07 & 0.14 & 0.19 & 0.09 & 0.09 & 0.14 & 0.10 & 0.12 \\
\hline $\begin{array}{c}\text { GRAD } \\
\text { ŠIROKI BRIJEG }\end{array}$ & 0.05 & 0.07 & 0.20 & 0.19 & 0.12 & 0.08 & 0.13 & 0.12 & 0.13 \\
\hline $\begin{array}{l}\text { BOSANSKO } \\
\text { GRAHOVO }\end{array}$ & 0.43 & 0.54 & 0.45 & 0.30 & 0.06 & 0.08 & 0.11 & 0.16 & 0.81 \\
\hline DRVAR & 0.16 & 0.07 & 0.37 & 0.22 & 0.08 & 0.12 & 0.09 & 0.12 & 0.25 \\
\hline GLAMOČ & 0.15 & 0.09 & 0.48 & 0.27 & 0.03 & 0.09 & 0.07 & 0.12 & 0.37 \\
\hline KUPRES & 0.14 & 0.12 & 0.24 & 0.3 & 0.19 & 0.10 & 0.05 & 0.22 & 0.28 \\
\hline LIVNO & 0.07 & 0.15 & 0.23 & 0.21 & 0.15 & 0.07 & 0.05 & 0.02 & 0.15 \\
\hline TOMISLAVGRAD & 0.16 & 0.11 & 0.22 & 0.16 & 0.12 & 0.05 & 0.05 & 0.04 & 0.13 \\
\hline
\end{tabular}

Variability evaluation method of socio-geographic and educational parameters

Metoda ocjene varijabilnosti sociogeografskih i obrazovnih parametara

Source: Statistical Yearbook of the Federation of Bosnia and Herzegovina $(2009,2010,2011,2012,2013,2014,2015,2016,2017,2018)$. Izvor: Statistički godišnjaci Federacije Bosne i Hercegovine (2009., 2010., 2011., 2012., 2013., 2014., 2015., 2016., 2017., 2018.) 
HRVATSKI GEOGRAFSKI

GLASNIK

81/2, 89-106 (2019.)
Tab. 2 Measure of variability of cantons in the Federation of Bosnia and Herzegovina

Tab. 2. Miera varijabilnosti po županijama u Federaciij Bosne i Hercegovine

\begin{tabular}{|l|c|}
\hline Una-Sana Canton / Unsko-sanska županija & 0.12 \\
\hline Posavina Canton / Posavska županija & 0.40 \\
\hline Tuzla Canton / Tuzlanska županija & 0.12 \\
\hline Zenica-Doboj Canton / Zeničko-dobojska županija & 0.19 \\
\hline Bosnian-Podrinje Canton Goražde/ Bosansko-podrinjska županija Goražde & 0.48 \\
\hline Central-Bosnia Canton / Srednjobosanska županija & 0.25 \\
\hline Herzegovina-Neretva Canton / Hercegovačko-neretvanska županija & 0.54 \\
\hline West Herzegovina Canton / Zapadnohercegovačka županija & 0.16 \\
\hline Sarajevo Canton / Sarajevska županija & 0.71 \\
\hline Canton 10/Županija 10 & 0.33 \\
\hline
\end{tabular}

Source: Statistical Yearbook of the Federation of Bosnia and Herzegovina $(2009,2010,2011,2012,2013,2014,2015,2016,2017,2018)$. Izvor: Statistički Godišnjaci Federacije Bosne i Hercegovine (2009., 2010., 2011., 2012., 2013., 2014., 2015., 2016., 2017., 2018.)

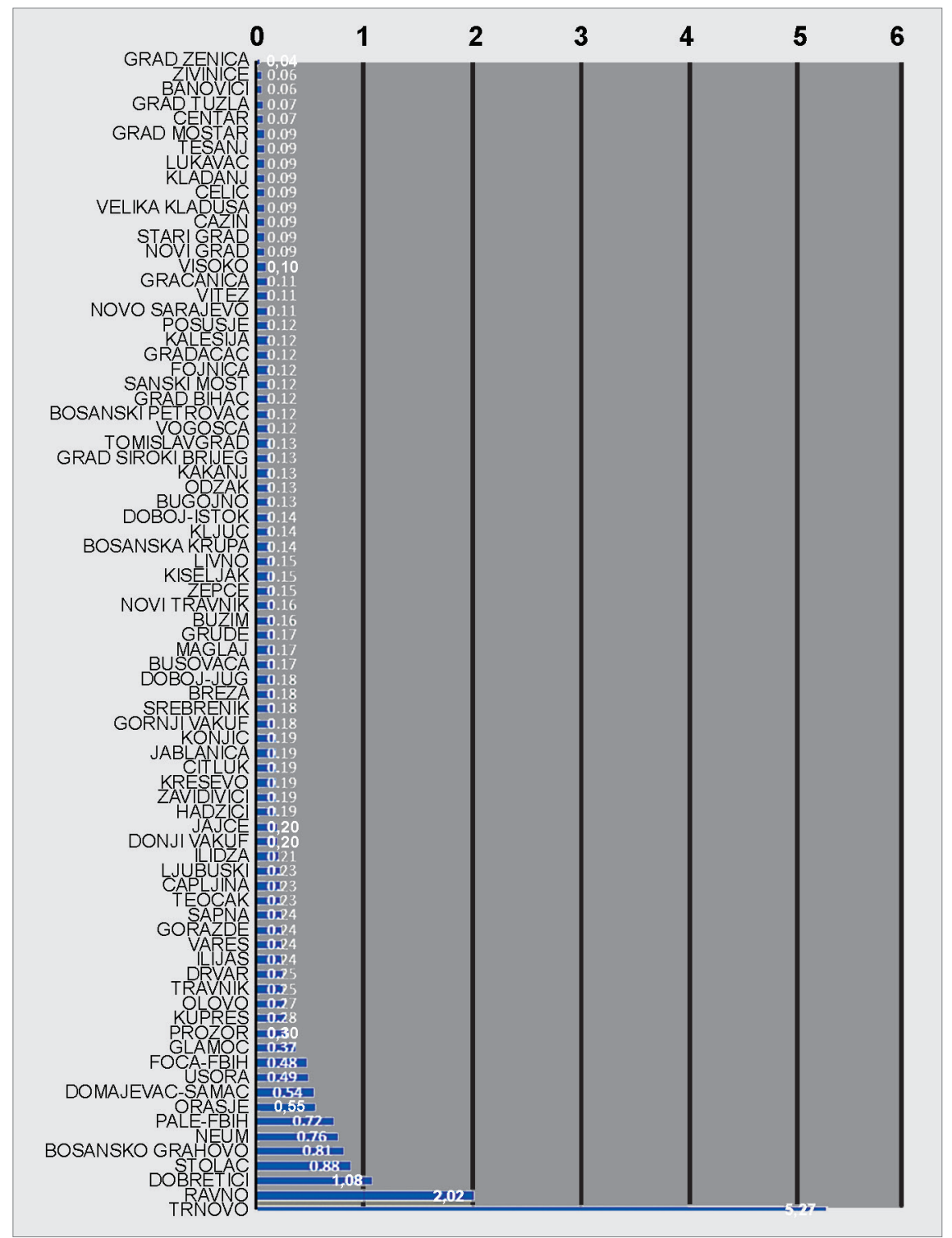

Fig. 1 Measures of variability by municipality

SI. 1. Općinska miera varijabilnosti

Source: Statistical Yearbook of the Federation of Bosnia and Herzegovina (2009., 2010. 2011., 2012., 2013., 2014., 2015. 2016., 2017., 2018.). Izvor: Statistički godišnjaci Federacije Bosne Hercegovine (2009., 2010. 2011., 2012., 2013., 2014., 2015. 2016., 2017., 2018.) 
Fig. 2 Histogram of measures of variability

SI. 2. Histogram mjere varijabilnosti

Source: Statistical Yearbook of the Federation of Bosnia and Herzegovina (2009., 2010., 2011., 2012., 2013., 2014., 2015., 2016., 2017., 2018.). Izvor: Statistički godišnjaci Federacije Bosne i Hercegovine (2009., 2010., 2011., 2012., 2013., 2014., 2015., 2016., 2017., 2018.)

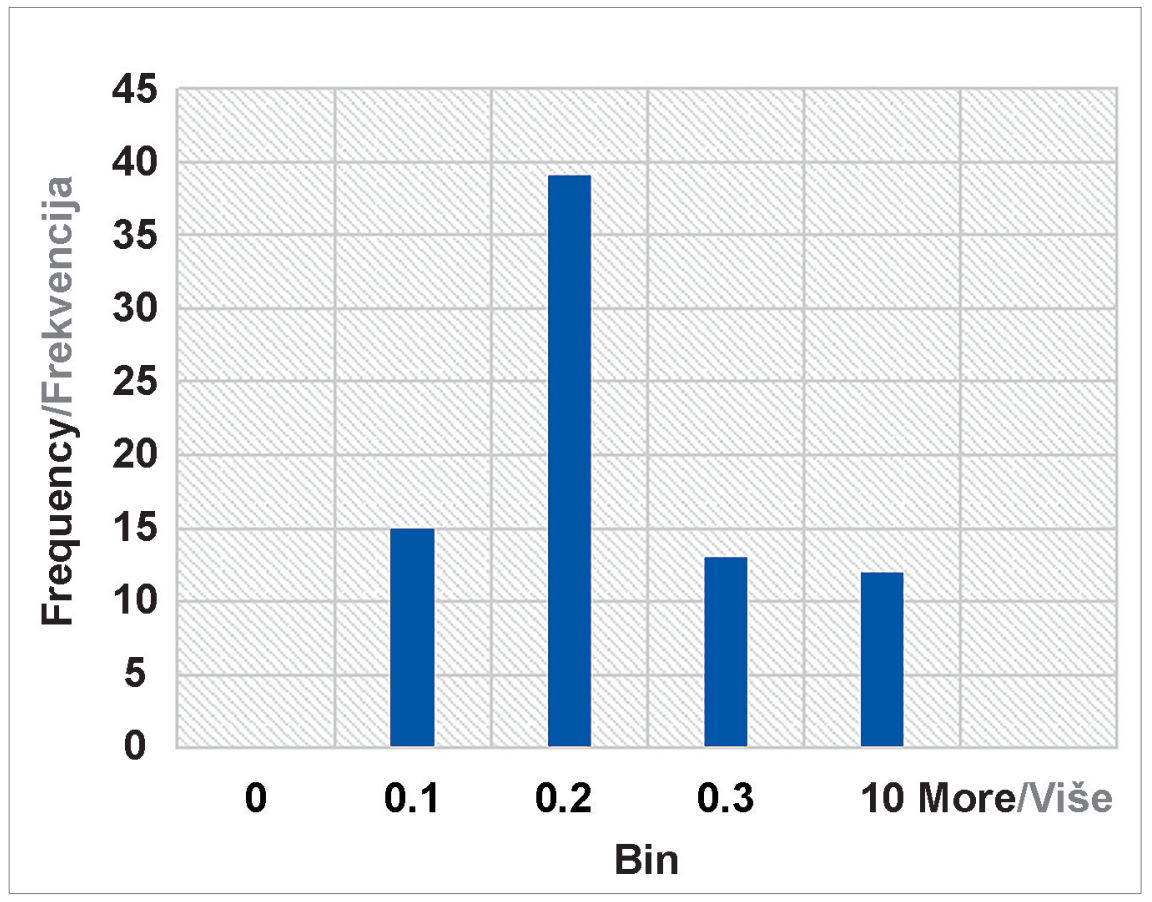

Kao što pokazuje histogram (sl. 2), postoji 15 općina s mjerom varijabilnosti između 0 i 0,1, 39 općina između 0,1 i 0,2, 13 općina između 0,2 i 0,3 i 12 općina s mjerom varijabilnosti većom od 0,3 (sl. 3). To podrazumijeva vrlo pozitivne sociogeografske i obrazovne parametre za 15 općina i izrazito negativne za 12 općina.

U sljedećem se odjeljku primjenjuje $k$-means grupiranje za dobivanje kategorizacije Federacije Bosne i Hercegovine u regije sličnih općina s obzirom na varijabilnost navedenih parametara. To pokazuje koje općine pripadaju istom rasponu varijabilnosti. parameters

Metoda ocjene varijabilnosti sociogeografskih i obrazovnih parametara

In the next section, $\mathrm{k}$-means clustering was applied to obtain a categorisation of the Federation in regions with similar municipalities with respect to variability of these parameters. This showed which municipalities belonged to the same range of variability. 
HRVATSKI

GEOGRAFSKI

GLASNIK

81/2, 89-106 (2019.)

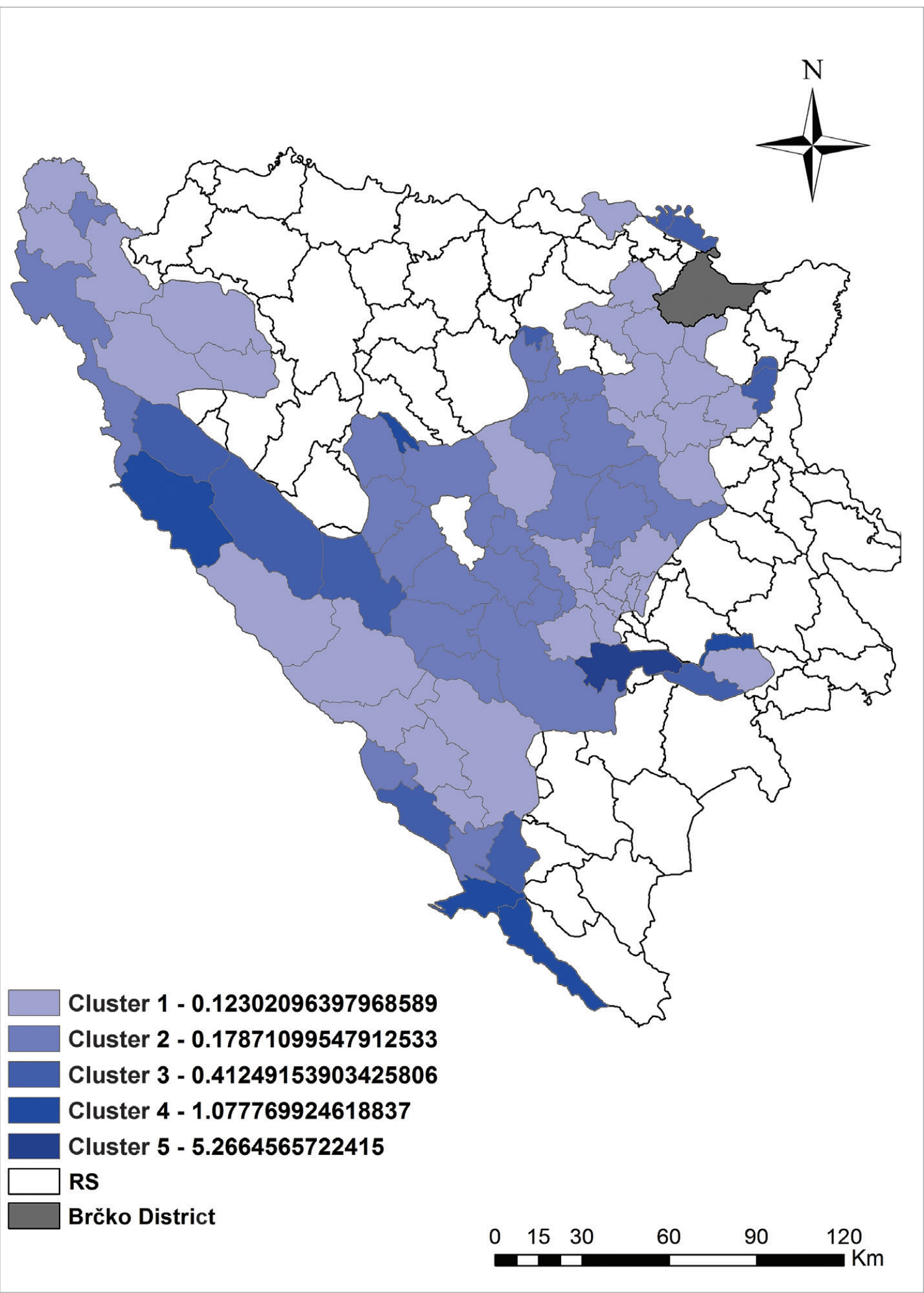

Fig. 3 The spatial coverage of 5 clusters with associated municipalities of the Federation of Bosnia and Herzegovina SI. 3. Prostorni obuhvat 5 klastera s pripadajućim općinama Federacije Bosne i Hercegovine 


\section{K-means clustering}

$\mathrm{K}$-means clustering is a widely-used tool for unsupervised learning and the classification of data into similar classes. It is included in most books that deal with Machine Learning and Data Science. This section uses k-means clustering to obtain a categorisation of municipalities of the Federation into similar classes according to selected socio-geographic and educational parameters (see Scholkopf and Smola, 2002).

\section{Let}

$$
\mathcal{D}=\{\chi(1), \ldots, \chi(m)\}
$$

be a set of municipalities in a given region of the state. Each municipality is represented as an eight-dimensional vector. K-means clustering with standard $\mathrm{Eu}-$ clidean distance is applied and $\mathrm{k}$ classes are obtained. Each of these classes represents municipalities with similar variability with respect to the selected $\mathrm{pa}^{-}$ rameters. Every parameter has equal influence when using Euclidean norm, which this paper contains.

Suppose there are some data $\left\{\chi^{(1)}, \ldots, \chi^{(m)}\right\}$ which are vectors in $\mathrm{R}^{n}$. The $\mathrm{k}$-means clustering algorithm partitions this dataset into $\mathrm{k}$ subsets in the following way. First it initializes cluster centroids $\mu_{1}, \ldots, \mu_{k} \in \mathrm{R}^{n}$ randomly. Then it repeats the following two steps until convergence:

1) for every $i$, set $c^{(i)}$ to be index $j$ for which $\| \chi^{(i)}-\left.\mu_{j}\right|^{2}$ is minimal,

2) for each $j$, set centroid to be mean value of all $\chi^{(i)}$ for which $c^{(i)}=\mathbf{j}$.

$\mathrm{k}$ subsets are formed in such a way that their elements have distance from their centroids minimised in square norm.

For $\mathrm{k}=5$, classes with appropriate measures of variability are obtained and shown in figure 3 .

\section{K-means grupiranje}

Široka je primjena $k$-means grupiranja kao alata u klasifikaciji podataka u slične razrede. To je dio gotovo svake tematike strojnoga učenja i znanosti o podatcima. Ovdje se $k$-means grupiranje koristi za dobivanje kategorizacije općina Federacije Bosne i Hercegovine u slične razrede za sociogeografske i obrazovne parametre (vidi Scholkopf i Smola, 2002).

\section{Neka je}

$$
\mathcal{D}=\{\chi(1), \ldots, \chi(m)\}
$$

skup općina u nekoj regiji države. Svaka se općina predstavlja kao osmodimenzionalni vektor. K-means grupiranje primjenjuje se sa standardnom euklidskom udaljenosti i dobiva se k-klasa. Svaka od tih klasa predstavlja općine sa sličnom varijabilnošću u odnosu na te parametre. Svaki parametar ima jednak utjecaj pri korištenju euklidske norme koju ovaj rad sadrži.

Pretpostavimo da su dani podatci $\left\{\chi^{(1)}, \ldots, \chi^{(m)}\right\}$ koji su vektori u $\mathrm{R}^{n}$. K-means grupiranje algoritama vrši particiju skupa podataka na k-podskupova na sljedeći način. Prvo inicijalizira centre klastera $\mu_{1}, \ldots, \mu_{k} \in \mathrm{R}^{n}$ slučajno. Tada ponavlja sljedeća dva koraka do konvergencije:

1) za svako i stavi $c^{(i)}$ da bude indeks $\mathrm{j}$ za koji je $\left\|\chi^{(i)}-\mu_{j}\right\|^{2}$ minimalno

2) za svako j stavi centar da bude srednja vrijednost $\operatorname{svih} \chi^{(i)}$ za koje $c^{(i)}=\mathbf{j}$.

k-podskupovi oblikovani su tako da su njihovi elementi udaljeni od svojih centara u kvadratnoj normi.

$\mathrm{Za} \mathrm{k}=5$ dobivene su klase s odgovarajućim mjerama varijabilnosti koje su prikazane na slici 3 . 
HRVATSKI GEOGRAFSKI GLASNIK 81/2, 89-106 (2019.)
For $k=10$ the results are as follows:

\subsection{8}

['CENTAR', 'NOVI GRAD', 'NOVO SARAJEVO', 'STARI GRAD', 'BOSANSKA KRUPA', 'BOSANSKI PETROVAC', 'CAZIN', 'GRAD BIHAĆ', 'KLJUČ', 'SANSKI MOST', 'VELIKA KLADUŠA', 'BANOVIĆI', 'ČELIĆ', 'DOBOJ-ISTOK', 'GRAČANICA', 'GRAD TUZLA', 'KALESIJA', 'KLADANJ', 'LUKAVAC', 'ŽIVINICE', 'ODŽAK', 'VISOKO', 'GRAD ZENICA', 'GRAD MOSTAR', 'POSUŠJE', 'GRAD ŠIROKI BRIJEG', 'LIVNO', 'TOMISLAVGRAD']

\subsection{5}

['BUŽIM', 'BREZA', 'DOBOJ-JUG', 'KAKANJ', 'MAGLAJ', 'OLOVO', 'TEŠANJ', 'USORA', 'VAREŠ', 'ZAVIDOVIĆI, 'ŽEPĆE', 'BUGOJNO', 'BUSOVAČA', 'DONJI VAKUF', 'FOJNICA', 'GORNJI VAKUF-USKOPLJE', 'JAJCE', 'KISELJAK', 'KREŠEVO', 'NOVI TRAVNIK', 'TRAVNIK', 'VITEZ', 'JABLANICA', 'KONJIC', 'PROZOR', 'GRUDE']

0.20010145924388056

['HADŽIĆI', 'ILIDŽA', 'ILIJAŠ', 'VOGOŠĆA', 'GRADAČAC', 'SREBRENIK', 'GORAŽDE', ‘ČAPLJINA', 'ČITLUK', 'KUPRES']

0.301786899006198

['SAPNA', 'TEOČAK', 'FOČA-FBIH', 'LJUBUŠKI', 'DRVAR', 'GLAMOČ']

0.5414880484473281

['DOMALJEVAC-ŠAMAC', 'ORAŠJE']

0.7594561171339448

['NEUM']

0.869076997161968

['PALE-FBIH', 'DOBRETIĆl', 'BOSANSKO GRAHOVO']

0.8777668201333126

['STOLAC']

2.0221625144743367

['RAVNO']

5.26645657522415

['TRNOVO-FBiH']
Za k = 10 rezultat je sljedeći:

\subsection{8}

['CENTAR', 'NOVI GRAD', 'NOVO SARAJEVO', 'STARI GRAD', 'BOSANSKA KRUPA', 'BOSANSKI PETROVAC', 'CAZIN', 'GRAD BIHAĆ', 'KLJUČ', 'SANSKI MOST', 'VELIKA KLADUŠA', 'BANOVIĆI', 'ČELIĆ', 'DOBOJ-ISTOK', 'GRAČANICA', 'GRAD TUZLA', 'KALESIJA', 'KLADANJ', 'LUKAVAC', 'ŽIVINICE', 'ODŽAK', 'VISOKO', 'GRAD ZENICA', 'GRAD MOSTAR', 'POSUŠJE', 'GRAD ŠIROKI BRIJEG', 'LIVNO', 'TOMISLAVGRAD']

\subsection{5}

['BUŽIM', 'BREZA', 'DOBOJ-JUG', 'KAKANJ', 'MAGLAJ', 'OLOVO', 'TEŠANJ', 'USORA', 'VAREŠ', 'ZAVIDOVIĆI', 'ŽEPČE', 'BUGOJNO', 'BUSOVAČA', 'DONJI VAKUF', 'FOJNICA', 'GORNJI VAKUF-USKOPLJE', 'JAJCE', 'KISELJAK', 'KREŠEVO', 'NOVI TRAVNIK', 'TRAVNIK', 'VITEZ', 'JABLANICA', 'KONJIC', 'PROZOR', 'GRUDE’]

\subsection{6}

['HADŽIĆI', 'ILIDŽA', 'ILIJAŠ', 'VOGOŠĆA', 'GRADAČAC', 'SREBRENIK', 'GORAŽDE', ‘ČAPLJINA', 'ČITLUK', 'KUPRES']

\subsection{8}

['SAPNA', 'TEOČAK', 'FOČA-FBIH', 'LJUBUŠKI', 'DRVAR', 'GLAMOČ']

0.5414880484473281

['DOMALJEVAC-ŠAMAC', 'ORAŠJE']

0.7594561171339448

['NEUM']

0.869076997161968

['PALE-FBIH', 'DOBRETIĆI', 'BOSANSKO GRAHOVO']

0.8777668201333126

['STOLAC']

2.0221625144743367

['RAVNO']

5.26645657522415

['TRNOVO-FBiH'] 


\section{Discussion}

It is clear that the Dayton Peace Agreement and its regulations regarding education and the formation of the post-war administrative and territorial structure is a major influencing factor on the current state of education, as well as the socio-economic structure of the entities of Bosnia and Herzegovina. By introducing the method of k-means clustering, it was possible to form 5 classes of municipalities in which the variation measures are different for each class. In the first, the most favourable class consists of the primarily-urban municipalities of Sarajevo Canton, municipalities or larger urban centres such as the City of Tuzla or the City of Zenica, the City of Široki Brijeg, and very promising and economically solid municipalities such as Visoko, Goražde, Živinice, Gradačac, Srebrenik, Lukavac, Banovići, and Cazin.

In the second class, municipalities from Central-Bosnia Canton and Zenica-Doboj Canton dominate, with a value of the variability measure rounded to two decimal places at 0.80 . These are municipalities that have a lower standard of living, lower potential of elementary school pupils, lower employment rate, and the space has negative values of natural and mechanical population movements.

In the third class, there are bordering and border municipalities, such as Orašje, Stolac, Ljubuški, Drvar, Domaljevac-Šamac, and Glamoč.

The fourth and fifth classes refer to municipalities where the measure of variability value exceeds the number 1, indicating the presence of expressly negative values of socio-economic parameters.

The number of pupils in the elementary schools of Bosansko Grahovo, Neum, Dobretići, Ravno, and Pale is decreasing and schools are closing. The main reason is a total exodus of population to other parts of the Federation or abroad. An exception is the municipality of Trnovo, where the variability measure value greater than 5 indicates significant changes in the number of inhabitants, especially in 2012. In this year, due to political circumstances and administrative tools, methodological determinants of the Population Census were able to be manipulated. Thus, in the same year, the municipality of Trnovo received a large number of newcomers from RS and this great difference in the total

\section{Rasprava}

Jasno je da su Dejtonski mirovni sporazum i njegovi propisi koji se odnose na obrazovanje i formiranje poslijeratne administrativne i teritorijalne strukture ostavili velik trag na kasnije stanje obrazovanja, kao i socioekonomsku strukturu entiteta Federacije BiH. Uvođenjem metode $k$-means grupiranja bilo je moguće formirati 5 klasa općina u kojima su varijacijske mjere različite za svaku klasu. U prvoj, najpovoljnijoj klasi prvenstveno su urbane općine Županije Sarajevo, općine ili veći urbani centri kao što su Grad Tuzla ili Grad Zenica, Grad Široki Brijeg i veoma perspektivne i privredno dobro funkcionirajuće općine kao što su Visoko, Goražde, Živinice, Gradačac, Srebrenik, Lukavac, Banovići i Cazin.

U drugoj klasi dominiraju općine Srednjobosanske županije i Zeničko-dobojske županije, čija je vrijednost mjere varijabilnosti zaokružena na dva decimalna mjesta na 0,80 . Riječ je o općinama nižega životnog standarda, niskoga potencijala učenika osnovnih škola, manje zaposlenosti i prostora koji imaju negativne vrijednosti prirodnoga i mehaničkoga kretanja stanovništva.

U trećoj su klasi pogranične i granične općine kao što su Orašje, Stolac, Ljubuški, Drvar, Domaljevac-Šamac i Glamoč.

Četvrta i peta klasa odnose se na općine u kojima vrijednost varijabilnosti prelazi broj $1 \mathrm{i}$ upućuje na zaključak o vrlo negativnim vrijednostima socioekonomskih parametara.

Broj učenika u osnovnim školama u općinama Bosansko Grahovo, Neum, Dobretići, Ravno i Pale-FBiH u opadanju je i dovodi do zatvaranja škola. Glavni je razlog potpuni egzodus stanovništva u druge dijelove Federacije Bosne i Hercegovine ili u inozemstvo. Iznimka je općina Trnovo $(\mathrm{FBiH})$, gdje vrijednost varijabilnosti veća od 5 upućuje na značajne promjene u broju stanovnika, posebno u 2012. godini. U toj se godini zbog političkih okolnosti i administrativnih odnosa moglo manipulirati metodološkim odrednicama popisa stanovništva i prijaviti se u drugim mjestima. Tako je iste godine općina Trnovo $(\mathrm{FBiH})$ primila velik broj stanovnika iz entiteta Republike Srpske i ta parameters

Metoda ocjene varijabilnosti sociogeografskih i obrazovnih parametara 
GEOGRAFSKI

GLASNIK

81/2, 89-106 (2019.) number of inhabitants manifested in the variability of socio-geographic parameters, due to which the natural and mechanical processes of the population showed significant irregularities.

When the ten classes are allocated according to the application of k-means clustering, it can be noticed that almost six classes, with the exception of the fifth and the seventh, have one municipality in their composition. This indicates that these are high values of the measure of variability as a result of the dynamic processes of reducing the natural and the total movement of the population for the same municipalities, insufficient birth rate and number of primary school pupils, high unemployment rate, years of low wages, and exodus of the population from already sparsely-populated municipalities. These processes have been identified by Emirhafizović and Zolić (2017).

\section{Conclusion}

Higher variability in certain clusters implies higher variability in cantons which contain municipalities in said clusters. Using this method, those municipalities were detected and a classification of the Federation, with respect to variability, was obtained. These variability classifications were based on the vectors of eight elements, which represented variability of certain parameters related to socio-geographic, educational, and economic aspects of life. There are several factors that led to these results. Some of them are related to large immigrations that took place one year before the 2013 Population Census. Others are related to economic issues, political instability, ethnic polarisation, and process of centralisation of settlements.

Polarisation processes in the Federation, especially after the war, have resulted in unequal socio-economic development and spatial redeployment of the population, as well as the concentration of population, jobs, and housing in urban settlements. Political and economic changes and the consequences of the war have deepened and accelerated the already unfavourable demographic processes, visible in the overall depopulation and deterioration of the structure of the population of the border cantons in the Federation. This has also created significant differences in primary and secondary education in Sarajevo Canton and some of velika razlika u ukupnom broju stanovnika manifestirala se u varijabilnosti sociogeografskih parametara, među kojima su prirodni i mehanički procesi stanovništva pokazali značajne nepravilnosti.

Ako se uzme u obzir 10 klasa shodno primjeni $k$-means grupiranja, može se opaziti da gotovo 6 klasa, s izuzetkom pete i sedme, ima samo jednu općinu u svom sastavu. Ovo upućuje na to da su visoke vrijednosti mjere varijabilnosti rezultat dinamičkih procesa smanjenja prirodnoga i ukupnoga kretanja stanovništva za iste općine, zatim nedovoljna broja rođene djece i učenika osnovnih škola, velika broja nezaposlenih osoba, niske vrijednosti prosječne neto plaće i egzodusa stanovništva iz već ionako rijetko naseljenih općina. Te su procese identificirali Emirhafizović i Zolić (2017).

\section{Zaključak}

Veća varijabilnost $\mathrm{u}$ određenim skupinama podrazumijeva veću varijabilnost u županijama koje imaju općine u tim skupinama. Ova metoda otkriva te općine i daje određenu klasifikaciju općina Federacije Bosne i Hercegovine u odnosu na varijabilnost. Klasifikacija varijabilnosti temelji se na vektoru osam elemenata koji predstavljaju varijabilnost pojedinih parametara vezanih za sociogeografske, obrazovne i privredne aspekte života. Postoji nekoliko razloga za dobivanje takvih rezultata. Neki su od njih povezani s golemim imigracijama godinu dana prije popisa stanovništva 2013. Ostali su povezani s privrednim pitanjima, političkom nestabilnošću, etničkom polarizacijom i procesom centralizacije naselja.

Polarizacijski procesi započeti u Federaciji Bosne i Hercegovine, posebno nakon rata, rezultirali su nejednakim socioekonomskim razvojem i prostornom preraspodjelom stanovništva te koncentracijom stanovništva, radnih mjesta i stanova u gradskim naseljima. Političke i ekonomske promjene i posljedice rata produbile su i ubrzale ionako nepovoljne demografske procese, što se odražava u ukupnoj depopulaciji i pogoršanju strukture stanovništva pograničnih županija u Federaciji Bosne i Hercegovine, ali su stvorile i značajne razlike $u$ osnovnom i srednjem obrazovanju u Županiji Sarajevo i nekim većim op- 
the larger municipal centres in relation to the border cantons and most of the smaller municipal centres.

The analysis of the measure of variability at the canton level (Tab. 2) shows the existence of two groups of cantons. In the first group are those cantons in which no specific changes or variations have been recorded in the last 10 years, and in which the negative demographic and economic-geographical processes trace from the War and post-War eras. These cantons have faced near-stagnant development for the last ten years, which is especially true for Una-Sana Canton, Zenica-Doboj Canton, and West Herzegovina Canton. On the other hand, Herzegovina-Neretva Canton, Bosnian-Podrinje Canton and Sarajevo Canton (second group) recorded significant changes in the measure of variability in which, however, different parameters played a key role, due to high values of the squared coefficient of variation. Precise values, however, point to the key role that was played in 2012, the year before the 2013 Population Census. In this year, the residents who dominated in the Canton Sarajevo and Tuzla Canton, were massively check out the place of residence in Federation in order to record in the smaller B\&H entity of Republika Srpska, first time after the war and post-war reconstruction. ćinskim centrima u odnosu na granične i većinu manjih općinskih centara.

Analiza mjere varijabilnosti na razini županija (tab. 2) pokazuje postojanje dviju skupina županija. U prvoj su skupini one županije u kojima nisu zabilježene nikakve posebne promjene ili varijacije u posljednjih 10 godina, u kojima su negativni demografski i ekonomsko-geografski procesi ostavili trag u ratu i poslijeratnom razdoblju. Te županije suočile su se s gotovo stagnirajućim razvojem u zadnjih deset godina, što se posebno odnosi na Unsko-sansku, Zeničko-dobojsku i Zapadnohercegovačku županiju. S druge strane, Hercegovačko-neretvanska, Bosansko-podrinjska županija Goražde i Županija Sarajevo (druga skupina) zabilježile su značajne promjene u mjeri varijabilnosti u kojoj su, međutim, različiti parametri odigrali ključnu ulogu u tako visokim vrijednostima kvadratnoga koeficijenta varijacije. Precizne vrijednosti, pak, upućuju na ključnu ulogu koja je odigrana 2012., godine prije službenoga popisa stanovništva i domaćinstava. U ovoj godini, stanovnici većinom iz Županije Sarajevo i Tuzlanske županije bili masovno odjavljeni iz lokalnih ustanova kako bi se evidentirali u manjem $\mathrm{BiH}$ entitetu Republika Srpska, prvi put nakon rata i poslijeratne obnove.
Bozic, G., 2006: Reeducating the hearts of Bosnian students: An essay on some aspects of education in Bosnia and Herzegovina, East European Politics \& Societies 20 (2), 319-342.

Emirhafizović, M., Zolić, H., 2017: Dobna struktura i reprodukcija stanovništva Bosne i Hercegovine, Demografske i etničke promjene u Bosni i Hercegovini, Akademija nauka i umjetnosti $\mathrm{BiH}$, Posebna izdanja, knj. 172, Odjeljenje društvenih nauka knj. 9., Sarajevo.

Jahić, H., 2015: Didaktičko-metodička analiza Okvirnog nastavnog plana i programa geografije u Federaciji Bosne i Hercegovine, Acta geographica Bosnia et Herzegovina 3 (1), 89-101.

Jancic, M., 2008: Education after conflict: perspectives on challenges to international agency policies in education in Bosnia and Herzegovina, Master Thesis, University of Oxford, Oxford.

Kozak, M., Bocianowski, J., Rybinsky, W., 2013: Note on the use of coefficient of variation for data from agricultural factorial experiments, Bulgarian Journal of Agricultural Science 19 (4), 644-646.

Mirić, R., 2011: Kompleksnost geografskib implikacija politicko-teritorijalne organizacije Bosne i Hercegovine u svijetlu savremenih evropskih integracijskih proce$s a$, doktorski rad, Univerzitet u Sarajevu, Sarajevo.

Pašalić-Kreso A., 1999: Education in Bosnia and Herzegovina: Minority Inclusion and Majority Rules - The System of Education in $\mathrm{BiH}$ as a Paradigm of Political Violence on Education, Current Issues in Comparative Education 2 (1), 6-13.

Pašalić-Kreso, A., 2008: The war and postwar impact on the educational system of Bosnia and Hercegovina, International Review of Education 54 (3/4), 353-374.

Reed, G. F., Lynn, F., Meade, B. D., 2002: Use of Coefficient of Variation in Assessing Variability of Quantitative Assays, Clinical and Diagnostic Laboratory
Immunology 9 (6), 1235-1239.

Scholkopf, B., Smola, A., 2002: Learning with kernels, Massachusetts Institute of Technology, London.

Stabback, P., 2007: Common curriculum, core curriculum or common curriculum standards-finding a solution for Bosnia and Herzegovina, Prospects: Quarterly Review of Comparative Education 37 (4), 449-467.

Torsti, P., 2003: Divergent Stories, Convergent Attitudes: Study on the Presence of History, History Textbooks and the Thinking of Youth in Post-War Bosnia and Hercegovina, $\mathrm{PhD}$ Thesis, University of Helsinki.

Torsti, P., 2007: How to deal with a difficult past? History textbooks supporting enemy images in post-war Bosnia and Hercegovina, Journal of Curriculum Studies 39 (1), 77-96.

Council of Ministers of Bosnia and Herzegovina/Vijeće ministara Bosne i Hercegovine, 2014: Strategija razvoja stručnog
A. Mehić

A. Memić

Variability

evaluation method of socio-geographic and educational parameters

Metoda ocjene varijabilnosti sociogeografskih i obrazovnih parametara

\section{Literature} Literatura 
HRVATSKI

GEOGRAFSKI

GLASNIK

81/2, 89-106 (2019.)

\section{Sources}

Izvori
Authors Autori obrazovanja i obuke u Bosni i Hercegovini za period 2007. - 2013. godine, http://fmon.gov.ba/Upload/Dokumenti/9c01ff86-8c2947c8-8adc-62a467bc5102_Strategija\%20razvoja\%20stru\%C4\%8Dnog\%20obrazovanja\%20i\%20 obuke\%20u\%20BiH\%20za\%20 period\%202007.-2013.\%20godine.pdf (21.01.2019.).

Council of Ministers of Bosnia and Herzegovina/Vijeće ministara Bosne i Hercegovine, 2008: Strateški pravci razvoja obrazovanja u Bosni i Hercegovini sa planom implementacije, 2008. - 2015., http://eurydice.ba/wp-content/uploads/2017/01/Usvojene-strategije-i-zakoni.pdf (18.12.2018.).

Federal Institute for Development Programming/ Federalni zavod za programiranje razvoja, 2010: Strategija razvoja Federacije BiH 2010. - 2020., Sarajevo, (07.03.2019.).

Federal Ministry of Education and Science/ Federalno ministarstvo obrazovanja i nauke, 2011: Informacija o upisu učenika u osnovne i srednje škole u Federaciji Bosne i Hercegovine u školskoj 2011/2012. godini, Mostar, 13.11.2018.).

Institute for Statistics of FBiH/ Federalni zavod za statistiku, 2003: Statistical Yearbook of the Federation Bosnia and Herzegovina in 2002/ Statistički Godišnjak Federacije Bosne i Hercegovine 2002. godine, http://fzs.ba/index.php/publikacije/statisticki-godisnjaciljetopisi/ (01.08.2018.)

Institute for Statistics of FBiH/ Federalni zavod za statistiku, 2007: Statistical Yearbook of the Federation Bosnia and Herzegovina in 2006./ Statistički Godišnjak Federacije Bosne i Hercegovine 2006. godine, http://fzs.ba/index.php/publikacije/statisticki-godisnjaciljetopisi/ (02.09.2019.)

Institute for Statistics of FBiH/ Federalni zavod za statistiku, 2011: Statistical Yearbook of the Federation Bosnia and Herzegovina in 2010./ Statistički Godišnjak Federacije Bosne i Hercegovine 2010. godine, http://fzs.ba/index.php/publikacije/statisticki-godisnjaciljetopisi/ (10.09.2019.).

Institute for Statistics of FBiH/ Federalni zavod za statistiku, 2014: Primary education in Federation of Bosnia and Herzegovina 2014. First Release Number 12.1./ Osnovno obrazovanje u Federaciji Bosne i Hercegovine 2014. Saopćenje broj 12.1., http://fzs.ba/index. php/publikacije/saopcenjapriopcenja/obrazovanje/ (23.02.2019.).

Institute for Statistics of FBiH/ Federalni zavod za statistiku, 2016: Primary education in Federation of Bosnia and Herzegovina in 2016., Statistical Bulletin Number 235./ Osnovno obrazovanje u Federaciji Bosne i Hercegovine 2016. Statistički Bilten 235., http:// fzs.ba/index.php/bosanski-bilteni/obrazovanje/ (05.01.2019.).

Institute for Statistics of FBiH/ Federalni zavod za statistiku, 2016: Primary education in Federation of Bosnia and Herzegovina in 2016., First Release Number 12.1./ Osnovno obrazovanje u Federaciji Bosne i Hercegovine 2016., Saopćenje broj 12.1., http://fzs. ba/index.php/publikacije/saopcenjapriopcenja/obrazovanje/ (03.12.2018.).

Institute for Statistics of FBiH/ Federalni zavod za statistiku, 2017: Primary education in Federation of Bosnia and Herzegovina in 2017., First Release Number 12.1./ Osnovno obrazovanje u Federaciji Bosne i Hercegovine 2017. Saopćenje broj 12.1., http://fzs. ba/index.php/publikacije/saopcenjapriopcenja/obrazovanje/ (03.12.2018.).

Institute for Statistics of FBH/ Federalni zavod za statistiku, 2017b: Demographics 2017/ Demografska statistika 2017., Statistical Bulletin 269/ Statistički Bilten 269., http://fzs.ba/index.php/2018/06/29/demografska-statistika-2017sb-269/ (17.01.2019.).

Institute for Statistics of FbiH/ Federalni zavod za statistiku, 2018a: Statistical Yearbook of the Federation Bosnia and Herzegovina in 2017./ Statistički Godišnjak Federacije Bosne i Hercegovine 2017. godine, http://fzs.ba/index.php/publikacije/statisticki-godisnjaciljetopisi/ (10.09.2019.).

Institute for Statistics of FBiH/ Federalni zavod za statistiku, 2018b: Primary education in Federation of Bosnia and Herzegovina in 2018., First Release Number 12.1/ Osnovno obrazovanje u Federaciji Bosne i Hercegovine 2018. Saopćenje broj 12.1., http://fzs.ba/ index.php/publikacije/saopcenjapriopcenja/obrazovanje/ (03.12.2018.).

Institute for Statistics of FBiH/ Federalni zavod za statistiku, 2018c: Estimate of the total population for the Federation of BiH, 2005.2017., First Release Number 14.2.1./ Procjena ukupnog broja stanovnika u Federaciji BiH, 2005. - 2017., Saopćenje broj 14.2.1., Sarajevo, http://fzs.ba/wp-content/uploads/2017/08/14.2.1.pdf/ (13.01.2019).

Amil Mehić amilmehic@hotmail.com

MSC in Geography, 3' year of Doctoral Study in Geography, University in Sarajevo, Faculty of Science, Department of Geography, Zmaja od Bosne 33-35,

71000 Sarajevo, Bosnia and Herzegovina

Alem Memić alem.memic@pmf.unsa.ba

Assistant Professor, University in Sarajevo, Faculty of Science, Department of Mathematics, Zmaja od Bosne 33-35,

71000 Sarajevo, Bosnia and Herzegovina 